\title{
Mangroves Sediment Ability as a Traps of Heavy Metal Chrome in Tukad Mati Estuary, Bali - Republic of Indonesia
}

\author{
I Gusti Ngurah Putra Dirgayusa ${ }^{1}$, Yulianto Suteja ${ }^{1} \&$ Ida Bagus Putu Adnyana ${ }^{2}$ \\ ${ }^{1}$ Faculty of Fishand Maritim, Udayana University, Bali, Indonesia \\ ${ }^{2}$ Faculty of Civil Engineering, Udayana University, Bali, Indonesia \\ Correspondence: Ida Bagus Putu Adnyana, Faculty of Civil Engineering, Udayana University, Bali, Indonesia. \\ Tel: 62-821-133-809-777. E-mail: bagusadnyana32@gmail.com
}

Received: January 18, $2017 \quad$ Accepted: May 9, $2017 \quad$ Online Published: July 30, 2017

doi:10.5539/jsd.v10n4p1

URL: https://doi.org/10.5539/jsd.v10n4p1

\begin{abstract}
Tukad Mati is one of the ten rivers has decreased due to the development of water quality screen printing and textile industries. Monitoring of the waters of the Tukad Mati has so far been confined to the Biological Oxygen Demand (BOD) and Chemical Oxygen Demand (COD) only. Whereas monitoring should be carried out thoroughly considering the heavy metal content is also harmful to users of water resources in Tukad Mati. One of the natural buffer of heavy metals in sediments of mangrove waters is a final media gathering all kinds of heavy metals waters, while mangrove itself is a natural sediment trap.

Therefore, the heavy metals in the waters will experience the highest accumulation in mangrove sediments. The purpose of this study is as early monitoring to detect the chromium metal in waters and sediments in Tukad Mati estuary. In this study conducted in on-site data measurements in the form of data $\mathrm{pH}$, temperature, salinity, disolved oxygen (DO) and discharge water. measurement of chromium content in the water and sediment of Tukad Mati estuary using AAS method.

The study showed that from the results of on-site data measurements in estuary of Tukad Mati showed that the average value of salinity, $\mathrm{pH}$, temperature and Dissolved Oxygen still meet quality ministerial decree of the environment of Indonesian Republic no 51 in 2004 for biota and marine tourism. The measurement results also showed that chromium content in water an average of $0.19(\mathrm{mg} / \mathrm{l})$ and exceed the ministerial decree of the environment of Indonesian Republic no 51 in 2004. Mangrove and non-mangrove sediments in Tukad Mati estuary have been exceed the Lowest Effect Level for organism and some sediment contaminated with chromium and passed the quality standards According to Canadian Council of Ministers of Environmental in 2000. Chromium concentration in sediment higer than water allegedly caused by heavy metals that tends to bind and fall to the bottom waters along the process of sedimentation.
\end{abstract}

Keywords: chromium heavy metals, mangrove sediments, Tukad Mati Estuary

\section{Background}

Tukad Mati is one of the top ten rivers in the province of Bali which decreased water quality. Monitoring has shown that Tukad Mati River is one of the rivers that run into pollution BOD, COD, oil and phosphate layer (Suarjana, 2013). Water quality degradation of Tukad Mati actually indicated the pollution resources. Screen printing and textile industry development along the river will be accompanied by increased waste (Eka, 2006). Screen printing and textile industry is one industry that can be done from a small or medium-scale household up. This resulted in the handling of waste generated through the cracks. Generally, the industry on this scale direct throw waste into sewers or rivers without any prior processing.

The textile industry produces colorless liquid waste and contains organic and inorganic materials is high, so that this waste has a BOD/COD is low and complex organic compounds that are difficult degraded (Budhi et al., 1999). The same thing happened in the screen printing industry have similar production processes. Waste textile/stencil produced from starch, removal of starch, cooking, maceration, dyeing, printing and process improvement (Pratiwi, 2010). The resulting dye textile industry generally containscomplex aromatic compounds that are difficult to decompose. This resulted in waste treatment that does not comply it will generate B3 waste in large enough quantities. In addition, this waste can threaten the life of the organism, particularly organisms that 
are generally used as material consumption.

Although it has been known to cause pollution, so far controlling and monitoring is performed only on the water quality in terms of BOD and COD, even though pollutants screen printing industry coming from the dyeing process to the production of film and plate processor that uses ink, solvent, diluent and dryer. These materials contain heavy metals such as chromium. Chromium is a heavy metal that forms the basis of pigments which are generally used in textile and screen printing. Waste that is directly discharged into the river, sooner or later will result in the addition of chrome metal ions in water. Khairani et al. (2007) explains that the waters of the excessive amount of chromium metal ion generally can not be consumed as drinking water. This is because the content of chromium in the water can cause health effects for humans.

One of the natural buffer of heavy metals in the water are mangrove sediments. Sediment is the final media gathering all kinds of heavy metals waters, while mangrove itself is a trap natural sediment quality. Therefore, the heavy metals in the waters will experience the highest accumulation in mangrove sediments. The existence of mangrove which is still quite heavy on the flow along Tukad Mati, especially on the estuary would be very helpful in reducing the metal chromium in natural waters. However, until now unknown degree of reduction of heavy metal chromium in water by mangrove sediments, especially in estuaries.

The existence of industrial waste textile and screen printing are the center of attention Tukad Mati management must be done thoroughly. The existence of pristine mangrove has great potential to help solve the waste problem. This research is important as early detection rate of absorption of heavy metals chromium in water by mangrove sediments. So that more research can provide policy advice enter or change legislation on science-based collaborative management that although the mangrove resource can be used by the general public around, but its management should also pay attention to the ecological benefits of mangrove. Therefore, the purpose of this study was to determine the water quality, heavy metals chromium in waters and sediments of mangrove in Tukad Matiestuary.

\section{Research Methodology}

Location of the research conducted at estuary of Tukad Mati, District of South Kuta, Badung, Bali Province, Republic of Indonesia. Location of the study and distribution of sampling points (Figure 1) is set with the following distribution: 5 sampling points in waters taken during the ups and downs, a 5 point sampling sediment in the water and sediment sampling mangrove 5 points right and left sides. Measurement of chromium in water and sediment done in Analytical Laboratories of Udayana University.

Sampling was done in 2 stages, the samples of water and sediment samples. Water sampling is done at high tide (flood) and low tide (ebb). Water sampling conducted in accordance with Andarani and Roosmini (2010), ie at half the total depth is $0,5 \mathrm{~d}$, as shown in Figure 2 . The sediment samples carried out only in estuarine areas. Water sampling is done by using a water sampler $250 \mathrm{ml}$ and preserved by adding HNO3. Then the sample bottle stored in a coolbox filled ice cubes. 


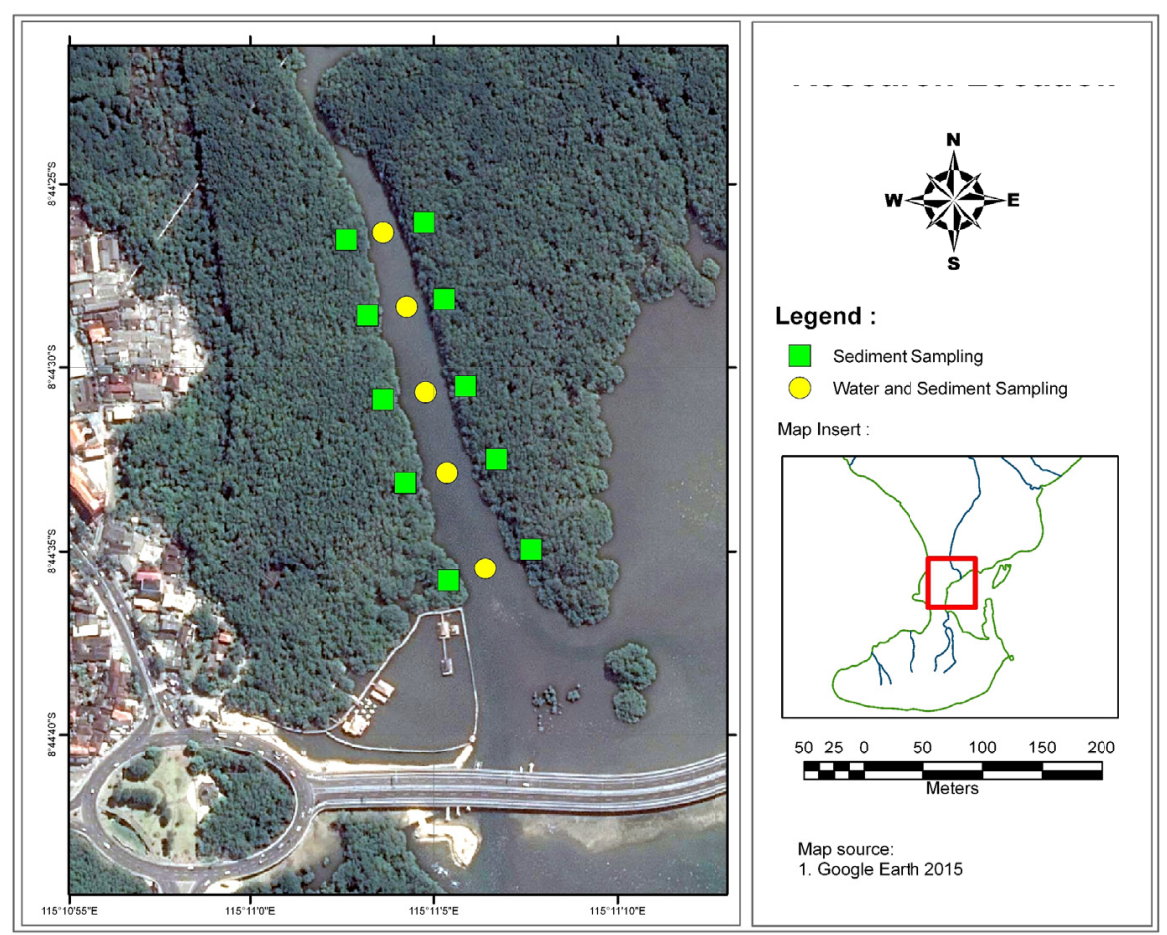

Figure 1. Location of the study and sampling point

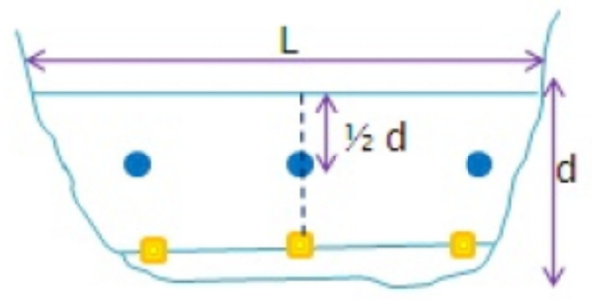

Water Sampel

Sediment Sampel

Figure 2. The cross section sampling sites for water and sediment sampel (Andarani and Roosmini, 2010)

The sediment samples were taken using ekman grab at each sampling point. sediment were taken in the middle side of ekman grab to avoid metal contamination from the use tools. Bottom sediments taken as much as $\pm 100 \mathrm{~g}$ of each station. Then the sample is inserted into black plastic bags stored in a coolbox.

In addition to conduct the sampling, each sampling point was also made insitu measurement data for environmental parameters namely $\mathrm{pH}$, temperature, salinity, $\mathrm{DO}$ and water discharge. Measurement parameters are performed using portable devices such as $\mathrm{pH}$-meter for $\mathrm{pH}$, thermometer for temperatiure, refractometer for salinity, and the DO-meter for Disolved Oxygen (DO). For water discharge, the measurement is done by calculating the cross sectional area of river runoff based on the physical character of river bodies, namely the width and depth of the river (Figure 3). 


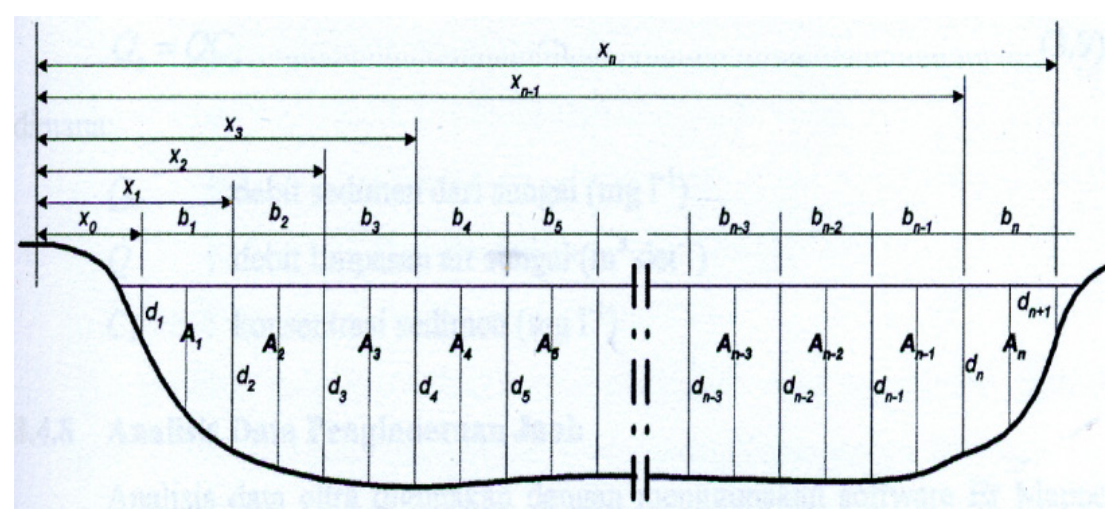

Figure 3. Cross-sectional area wet (A) (Source: Surbakti, 2010)

Based on the picture above the river sectional area measurements using the formula trapezoidal area with the following formula:

$$
\left.\mathrm{A}=\frac{\text { Side-by-side parallel }}{2} \text { (height }\right)
$$

Remarks:

$A$ : trapezoidal area $\left(\mathrm{m}^{2}\right)$

$d$ : side-by-side parallel (m)

$x$ : height (m)

Calculation of the wet cross-sectional area (A) was performed using the interval method middle (mid section) by the following equation (Chow, 1989 in Surbakti, 2010):

$$
A_{i}=\frac{d_{i}+d_{i+1}}{2}\left(x_{i}-x_{i-1}\right)=\frac{d_{i}+d_{i+1}}{2} b_{i}
$$

Remarks:

$i$ : number of segments (sub) cross-section; $\mathrm{i}=1,2,3, \ldots, n$;

$n$ : number of cross-sectional segments

Thus obtained the total cross-sectional area wet by using the equation:

$$
\mathrm{A}=\sum_{i=1}^{n} A_{i}=A_{1}+A_{2}+A_{3}+\ldots+A_{n}
$$

Debit per sub-sectional $\left(Q_{i}\right)$ calculated by the equation Gordon et al. (1992) in Surbakti, 2010 the following:

Remarks:

$$
Q_{i}=A_{i} \bar{V}_{l}
$$

$A_{i}$ : sub-sectional area of the river or canal to- $i\left(\mathrm{~m}^{2}\right)$

$\bar{V}_{l}:$ speed average river flow cross section into sub- $i(\mathrm{~m} / \mathrm{det})$.

In order to obtain the value of river discharge runoff water can be obtained through the equation:

$$
\mathrm{Q}=\sum_{i=1}^{n} Q_{i}=Q_{1}+Q_{2}+Q_{3}+\ldots+Q_{n}
$$

Analysis of heavy metals chromium in water and sediment samples using Inductively Coupled Plasma Emission (ICPE) 9000 Spectroscopy and detection limit is 0.001 . ICPE spectrophotometry produces high-temperature plasma by high ionization argon with high frequency $(27.12 \mathrm{MHz}$ ). The sample is sucked and atomized by a nebulizer which is then streamed to the plasma to stimulate the elements in the sample, thus causing the $\mathrm{Cr}$ element in the sample to emit plasma light. Preparation of water samples is done by referring to American Public Healt Association (APHA) (2012). For the sediment sample was done wet spraying first, by adding $\mathrm{HNO}_{3}$ and $\mathrm{H}_{2} \mathrm{SO}_{4}$ (Yenrina, 2015). After that, the sediment sample is treated the same as the water sample.

The data were analyzed descriptively and compared to ministerial decree of the environment of Indonesian Republic no 51 in 2004 for marine biota and maritime tourism . 


\section{Results and Discussion}

\section{A. Parameter On-site}

The results of measurements of salinity in the Tukad Mati estuary show that the highest salinity at high tide get an average of 26.4 psu and at the lowest salinity get when low tide is $7.5 \mathrm{psu}$ (Figure 4), it is quite natural to happen because, according to Stewart (2002) at high tide the sea water (saline) will go into the estuary at low tide and fresh water (low salinity) is the dominant sign. The results of this study also showed the same results as that obtained by Purwiyanto and Agustriani (2017) arround Payung Island, South Sumatera.

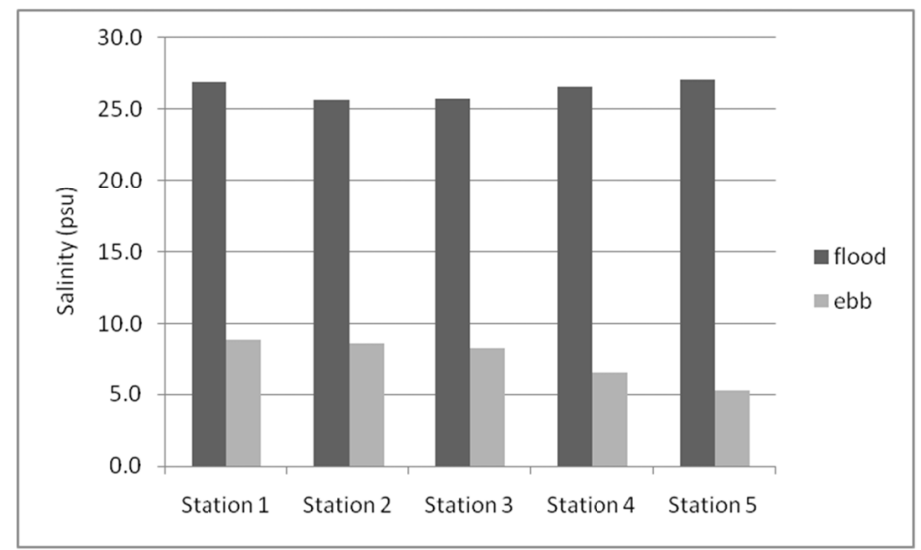

Figure 4. The salinity (psu) of Tukad Mati estuary surface water

At high tide, the salinity of sea water tendency ride from station 2 to station 5 it is due time measurements made when the water towards the post, while at the receding trend of salinity waters decreased from station 1 to station 5 , and this is because the influx of freshwater into the estuary. Station 1 at low water has a highest salinity ( 8.8 psu) because the station closer to the ocean while station 5 has more salinity lowest (5.5 psu) because of its position closer towards the river (Figure 1), in addition to the measurement time greatly affected too the size of the amount of fresh water entering. According to ministerial decree of the environment of Indonesian Republic no 51 in 2004, salinity waters of Tukad Mati estuary unspoiled and fulfill the quality standards for marine biota and maritime tourism.

The degree of acidity $(\mathrm{pH})$ is an acid-base level a solution that is measured from a scale of $0-14$. Results of $\mathrm{pH}$ (Figure 5) measurement Tukad Mati estuary waters at low tide it was found that the lowest $\mathrm{pH}$ at station 3 is equal to 7.37, the highest in get on station 4 is equal to 7.44. At high tide, the lowest $\mathrm{pH}$ obtained at station 3 is equal to 7.37 and the highest $\mathrm{pH}$ got on station 2 is equal to 7.73. Overall, $\mathrm{pH}$ alkaline waters tend to Tukad Mati better at high tide or low tide with a value range of 7.37 - 7.73. $\mathrm{pH}$ estuary and the sea tend to base because properties as a pH buffer of sea water, according to Frankignoulle (1994) and Bates and Mathis (2009) that comes from carbonate $\left(\mathrm{CO}_{3}{ }^{2-}\right)$ and hydrogen carbonate $\left(\mathrm{HCO}_{3}{ }^{-}\right)$ion. The $\mathrm{pH}$ value is almost as well in getting by Kaban et al., (2010) in the estuary of the Musi, Batang, and Indragiri River ranging form 7.5 to 8 and Abowei (2010) in Nkoro River, Niger Delta, Nigeria ranging from 7.3-7.7.

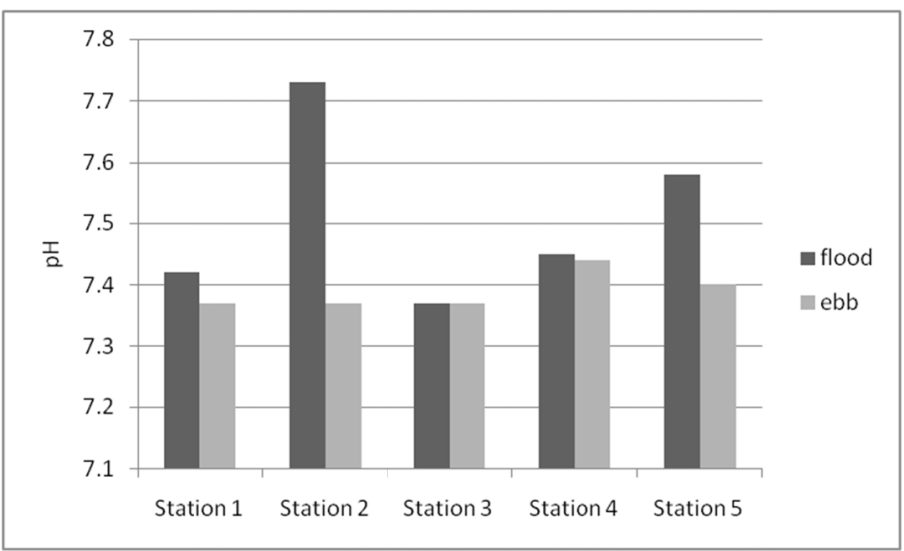

Figure 5. The $\mathrm{pH}$ of Tukad Mati estuary surface water 
Results of $\mathrm{pH}$ measurement in Tukad Mati estuary also showed no significant differences at high tide or low tide. This is presumably because at high tide or low tide, Tukad Mati estuarine waters still get the effect of sea water as evidenced by high salinity of the waters (Figure 4). The $\mathrm{pH}$ value obtained in the estuary Tukad Mati is smaller compared with the results of measurements of $\mathrm{pH}$ on the seas that average more than 8 (Rerolle et al, 2016), it is suspected because the estuary is meeting place for fresh water and sea water, where fresh water tends character neutral ( $\mathrm{pH} 7)$. Howland et al (2000) also explain that the $\mathrm{pH}$ of river water is low because its dominted by porrly buffer substance. According to ministerial decree of the environment of Indonesian Republic no 51 in 2004 , a pH of 7 to 8.5 is still fulfill the water quality standards for marine and maritime tourism.

The results of temperature measurements in Tukad Mati estuarine waters at high tide and low tide can be seen in Figure 6. At high tide the water temperature ranged between $27,4-27,9^{\circ} \mathrm{C}$ and peraian at low temperatures ranging between $26.7-27,3^{\circ} \mathrm{C}$. Temperature measurements on-site showed that the temperature of the waters of Tukad Mati estuary higher at flood (average $27.8^{\circ} \mathrm{C}$ ) and low at ebb (average rat $26.9^{\circ} \mathrm{C}$ ). The temperature difference is presumably due to the measurement of time, where the temperature measurement when the tide is done when the sun has an inclination angle is large at around $10.00 \mathrm{am}$ to $11.30 \mathrm{pm}$, whereas during low tide occur every day at 16:30 to 18:00 when the sun has a small inclination angle. According to Pond and Pickard (1983) the greater the inclination angle of the sun, the water temperature will be higher. According to ministerial decree of the environment of Indonesian Republic no 51 in 2004, the temperature of the waters of Tukad Mati estuary still fulfill the water quality standards for marine and maritime tourism.

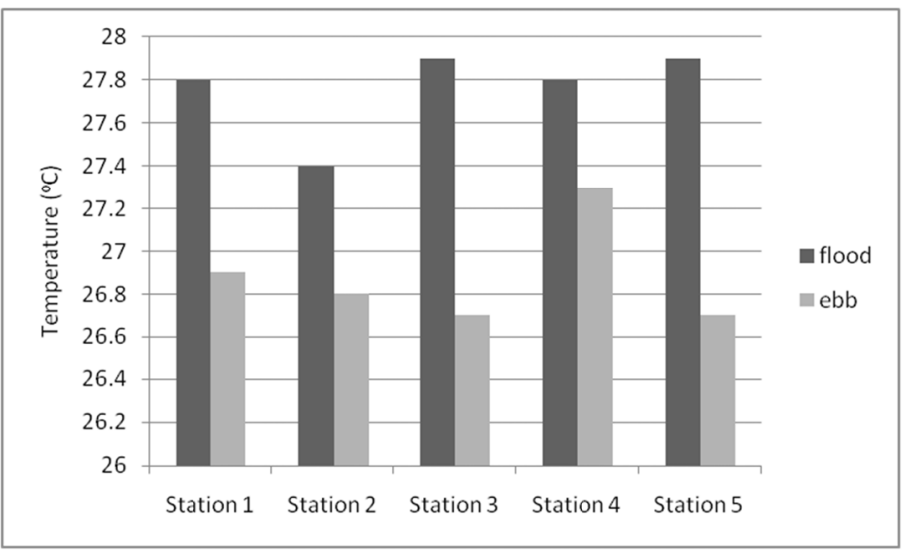

Figure 6. The Temperature $\left({ }^{\circ} \mathrm{C}\right)$ of Tukad Mati estuary surface water

The result of the measurement of DO indicates that the tendency of the value of DO at flood is higher than at ebb (Figure 7), it is assumed that at the time of pairs of Tukad Mati estuarine water has many inputs from clear sea water (visual observation). These DO was found similar with Abowei (2010) in Nkoro River, Niger Delta Nigeria ranging form $3.2 \mathrm{mg} / 1$ to $7.3 \mathrm{mg} / \mathrm{l}$. The level of water clarity will greatly affect to the penetration of sunlight that will affect the process of photosynthesis done by phytoplankton. In addition, sea water is an excellent growth medium for phytoplankton growth. At low tide, the Tukad Mati estuarine water have the maximum input from the river water that have high turbidity (visual observation). High turbidity of the waters will cause the penetration of light for photosynthesis phytoplankton process will be reduced so that the production of DO will also be less. Abowei (2010) also explain that turbidity affect oxygen content.

According to ministerial decree of the environment of Indonesian Republic no 51 in 2004, when the DO content at low tide station $2(4.2 \mathrm{mg} / \mathrm{l})$ and 5 stations $(3.6 \mathrm{mg} / \mathrm{l})$ is not suitable for marine and nautical tourism because dissolved oxygen content is less of $5 \mathrm{mg} / \mathrm{l}$. The low oxygen content results in this station in the suspect because of the level of muddiness and the river water input on-site observations. If averaged, dissolved oxygen content Tukad Mati estuarine water still fulfill the quality standards for marine and maritime tourism. 


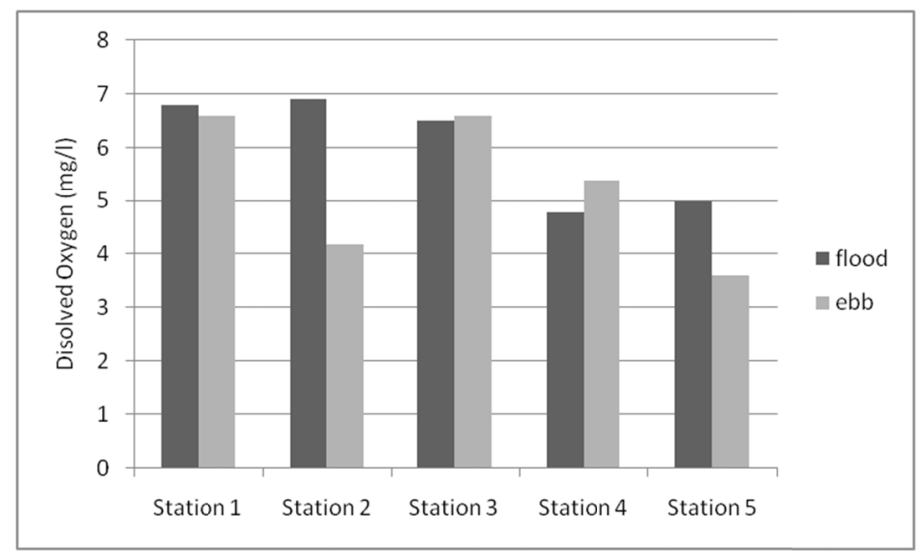

Figure 7. The dissolved oxygen $(\mathrm{mg} / \mathrm{l})$ of Tukad Mati estuary surface water

\section{B. Content of Chromium}

The measurement results of chromium metal content in Tukad Mati estuary waters showed that the concentration at flood (an average $0.24 \mathrm{mg} / \mathrm{l}$ ) higher than at ebb (an average of $0.06 \mathrm{mg} / \mathrm{l}$ ) (Figure 8). At flood, the estuary of Tukad Mati chromium content ranges from 0.17 to $0.36 \mathrm{mg} / \mathrm{l}$ and at low tide between $0-0.11 \mathrm{mg} / \mathrm{l}$. No detection of chromium at low tide on the expected concentration of chromium is smaller than the ability of detection equipment. In addition, at low water input predominant taste of river water (seen from salinity data in Figure 4) which has a lower salinity, according to Sanusi and Putranto (2009) at the time of low salinity trends of heavy metal does not bind with each other so that the concentration in the water column becomes low. Chromium content in Muara Tukad Mati has a higher concentration compared to that in the can Apriadi (2005) in Kamal Muara who just $0-0.0032 \mathrm{mg} / \mathrm{l}$ and Gitarama et al (2016) in the Cimanuk Lama River that range 0.010, 0.016 $\mathrm{mg} / \mathrm{l}$, but these concentration is lower than that obtained by Srichandan et al (2016) in surface sea water in Bengal Bay range from 0.2 to $1.57 \mathrm{ppb}$. Differences in upstream activities in the suspect becomes a major factor chromium content of this distinction.

At high tide the concentration of chromium metal will increase dramatically (Figure 8) because chromium is high solubility and aviability and difficult to degradation and will tend to accumulate in the water column (Kotas and Stasicka, 2000; Pawlikowski et al.,2006; Biswas et al, 2017;) as well as the tendency of metals to bind with other compounds to be higher (Sanusi and Putranto, 2009). Additionally in height concentration at high tide suspected to be caused by the accumulation of chromium metal contained in Benoa bay. Benoa bay is one example of the gulf that has a closed water circulation so that pollution into the marine environment will tend to accumulate. From the measurement results in also get that at high tide the sea water discharge goes into Tukad Mati estuary amounted to $22.79 \mathrm{~m}^{3} / \mathrm{s}$, while at low tide only $4.06 \mathrm{~m}^{3} / \mathrm{s}$. meanwhile, when the tide had chromium concentration in the water column so high that the input will add metal that goes into Tukad Mati estuary. When compared with the quality standards issued by ministerial decree of the environment of Indonesian Republic no 51 in 2004, the threshold values for Cr in waters, particularly for marine and maritime tourism is $0,005 \mathrm{mg} / \mathrm{l}$, the content of $\mathrm{Cr}$ in the waters of Muara Tukad Mati in general have exceeded the threshold value.

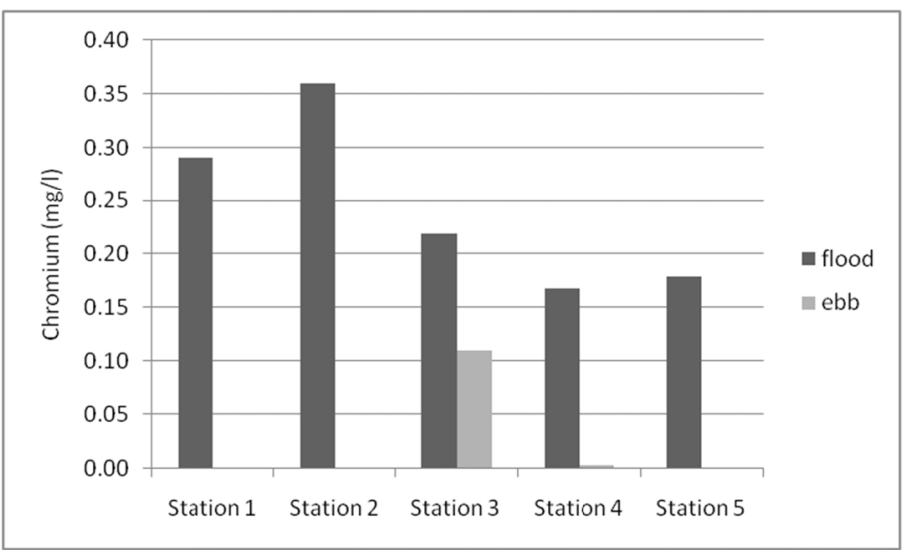

Figure 8 . The chromium (mg/l) of Tukad Mati estuary surface water 
The results of chromium measurements in non-mangrove sediments ranged from 2.71 to $55.72 \mathrm{mg} / \mathrm{kg}$ with an average of $37.07 \mathrm{mg} / \mathrm{kg}$, whereas for mangrove sediments ranged from 11.61 to $66.73 \mathrm{mg} / \mathrm{kg}$ with an average of $34.96 \mathrm{mg} / \mathrm{kg}$ (figure 9). It is suspected because of the non mangrove sediments get input high of dredging activity in Tukad Mati bodies on top. Dredging causes mud contained chromium has been piling up at the bottom of the river will move to other locations due to be carried away by the flow of the river.

The content of chromium in the sediment Tukad Mati estuary is much greater than the chromium content in the water column (Figure 8). According to Sanusi and Putranto (2009), heavy metals will tend to bind with other compounds (such as sediment) when entering the estuary and will drop to aquatic sediments if its density is greater than the density of water. Similar results were also obtained by Apriadi (2005) in Kamal estuary waters that contain kromiun in sediments of 0.087 to $13.15 \mathrm{mg} / \mathrm{kg}$. According to Canadian Council of Ministers of Environmental (2001) the Interim Sedimen Quality Guidelines (ISQL) is $37.7 \mathrm{mg} / \mathrm{kg}$ for fresh water and 52.3 $\mathrm{mg} / \mathrm{kg}$ for sea water, its mean that some of mangrove and non mangrove sediment in Tukad Mati estuary exceed the maximum limit. Base on average chromium heavy metal in mangrove and non mangrove sediment in Tukad Mati estuary are categorized as polluted, because according to MacDonald et al. (2000) that the limit of Lowest Effect Level (LEL) is only $26 \mathrm{mg} / \mathrm{kg}$. The organism that living in Tukad Mati estuary is not safe and potentially contaminated by chromium because organisms are expected life below this concentration.

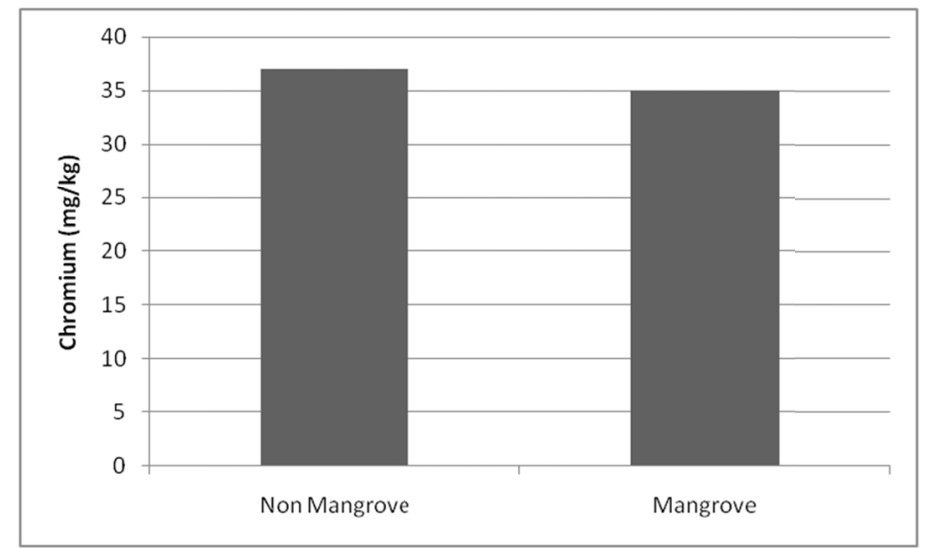

Figure 9. The content of chromium in sediment of Tukad Mati estuary

\section{Conclusion}

From these results it can be concluded that the results of on-sitedata measurements in Muara Tukad Mati showed that the average value of salinity (5.3 to $27.0 \mathrm{psu}), \mathrm{pH}$ (7.39 to 7.73), temperature (26.7 -27.9 oC) and Dissolved Oxygen (3.6 to $6.9 \mathrm{mg} / \mathrm{l}$ ) still meet quality standards according to ministerial decree of the environment of Indonesian Republic no 51 in 2004 for biota and marine tourism. The measurement results also showed that chromium in water content average of $0.19(\mathrm{mg} / \mathrm{l})$, mangrove sediments of $34.97 \mathrm{mg} / \mathrm{kg}$ and non-mangrove sediments of $37.07 \mathrm{mg} / \mathrm{kg}$. This shows Tukad Mati estuary waters have been exceed the Lowest Effect Level for organism and some sediment contaminated with chromium and passed the quality standards According to Canadian Council of Ministers of Environmental in 2000.

\section{Acknowledgments}

The authors would like to thank the Udayana University that has funded this research through a Hibah Unggulan Program Studi scheme. Author also thanks Anna Ida Sunaryo Purwiyanto who has provided many inputs for improvement this paper.

\section{References}

Abowei, JFN. (2010). Salinity, Dissolved Oxygen, pH and Surface Water Temperature Conditions in Nkoro River, Niger Delta, Nigeria. Advance Journal of Food Science and Technology, 2(1), 36-40.

Andarani, P., \& Roosmini, D. (2010). Profil Pencemaran Logam Berat (Cu, Cr, Dan Zn) Pada Air Permukaan Dan Sedimen Di Sekitar Industri Tekstil Pt X (Sungai Cikijing). Retrieved February 16, 2015, from http://www.ftsl.itb.ac.id/kk/teknologi_pengelolaan_lingkungan/wp-content/uploads/2010/10/PI-Pertiwi-And arani-15305045.pdf

APHA. (2012). Standard Methods for the Examination of Water and Wastewater (22 ${ }^{\text {th }}$ ed.). American Public Health Association. Washington DC. 
Apriadi, D. (2005). Kandungan Logam Berat Hg, Pb dan Cr Pada Air, Sedimen dan kerang hijau (perna viridis 1.) di perairan kamal Muara, teluk Jakarta. Thesis. Bogor Agricultural University: Bogor.

Bates, N. R., \& Mathis, J. T. (2009). The Arctic Ocean Marine Carbon Cycle: Evaluation Of Air-sea $\mathrm{CO}_{2}$ Exchanges, Ocean Acidification Impacts And Potential Feedbacks. Biogeosciences, 6, 2433-2459.

Biswas, P., Karn, A. K., Balasubramanian, P., \& Kale, P. G. (2017). Biosensor for detection of dissolved chromium in potable water: A review. Biosensors and Bioelectronics, 94, 589-604. https://doi.org/10.1016/j.bios.2017.03.043

Budhi, Y. W., Setiadi, T., \& Harimurti, B. (1999). Peningkatan biodegradabilitas limbah cair printing insudtri tekstil secara anaerob. Prociding of seminar teknik kimia Soehadi Reksowardojo. ITB. 19-20 Oktober 1999.

Eka. (2006). Pencemaran limbah sablon di Denpasar - "Cemari”kota berwawasan budaya. BaliPost, 23 $\begin{array}{lllll}\text { Agustus } 2006 . & \text { Retrieved } & \text { February 2015, from }\end{array}$ http://www.balipost.co.id/balipostcetak/2006/8/23/b22.htm

Frankignoule, M. (1994). A Complete Set of Buffer Factors For Acid /Base $\mathrm{CO}_{2}$ System in Sea Water. Journal of Marine Systems, 5(2), 111-118. https://doi.org/10.1016/0924-7963(94)90026-4

Gitarama, A. M., Krisanti, M., \& Agungpriyono, D. R. (2016). Komunitas Makrozoobentos dan Akumulasi Kromium di Sungai Cimanuk Lama, Jawa Barat. Jurnal Ilmu Pertanian Indonesia (JIPI), 21(1), 48-55.

Howland, R. J. M., Tappin, A. D., Uncles, R. J., Plummer, D. H., \& Bloomer, N. J. (2010). istributions and seasonal variability of $\mathrm{pH}$ and alkalinity in the Tweed Estuary, UK. The Science of the Total Environment, 251-252; 125-138. https://doi.org/10.1016/S0048-9697(00)00406-X

Kaban, S., Eko, P., \& Solekha. (2010). Telaah Salinitas Dan Oksigen Terlarut Di Muara Sungai Pantai Timur Sumatera. Prociding of Seminar Nasional Limnologi V in 2010.

Khairani, N., Azam, M., Sofjan, K., \& Soeleman, F. (2007). Penentuan Kandungan Unsur Krom dalam Limbah Tekstil dengan Metode Analisis Pengaktifan Neutron. Berkala Fisika, 10(1), 35-43.

Kotas, J., \& Stasicka, Z. (2000). Chromium occurrence in the environment and methods of its speciation. Environmental Pollution, 107(3), 263-283. https://doi.org/10.1016/S0269-7491(99)00168-2

MacDonald, D. D., Ingersol, C. G., \& Berger, T. A. (n.d.). Development and Evaluation of Consensun-Based Sediment Quality Guidline For Freshwater Ecosytem. Archieves of Environmental Contamination and Toxicology, 39(5), 20-31.

Neff, J. M. (2002). Bioacumullation in Marine Organisme. Effect of contaminants from oil well produced water. Elsevier Ltd.: Amesterdam.

Pawlikowski, M., Szalinska, E., Wardas, M., \& Dominik, J. (2006). Chromium originating from tanneries in river sediments: a preliminary investigation from the upper Dunajec River (Poland). Polish Journal of Environmental Studies, 15(6), 885-894.

Pond, S., \& Pickard, G. L. (1983). Introductory Dynamical Oceanography. Ed ke-2. Oxford: Pergamon Press.

Pratiwi, Y. (2010). Penentuan Tingkat Pencemaran Limbah Industri Tekstil Berdasarkan Nutrition Value Coefficient Bioindikator. Jurnal Tekhnologi, 3(2), 129-137.

Purwiyanto, A. I. S., \& Agustriani, F. (2017). Assessment of Carbon Status in Marine Protected Area of Payung Island Waters, South Sumatera Province, Indonesia. Indonesian Journal of Marine Science, 22(1), 1-6.

Rerolle, V., Ruiz-Pino, D., Rafizadeh, M., Loucaides, S., Papadimitriou, S., Mowlem, M., \& Chen, J. (2016). Measuring pH in the Arctic Ocean: Colorimetric. methodorSeaFET?. Method in Oceanography, 17, 32-49. https://doi.org/10.1016/j.mio.2016.05.006

Sanusi, H. S., \& Putranto, S. (2009). Kimia laut dan pencemaran. Proses Fisika kimia dan interaksinya dengan lingkungan. Bogor Agricultural University: Bogor.

Sricandan, S., Panigray, R. C., Baliarsingh, S. K., Rao, S. B., Pati, P., Sahu, B. K., \& Sahu, K. C. (2016). Distribution of trace metals in surface seawater and zooplankton of the Bay of Bengal, off Rushikulya estuary, East Coast of India. Marine Pollution Bulletin, 114(2), 1141-1151. https://doi.org/10.1016/j.marpolbul.2016.06.099

Stewart, R. H. (2002). Introduction to Physical Oceanography. Texas A \& M University: Departement of Oceanography. 
Suarjana, I. G. (2013). Masalah Lingkungan Bali Berat. Retrieved February 13, 2015, from http://www.baliprov.go.id/id/Masalah-Lingkungan-Bali--Berat-dan-Sulit-Pemprov-Programkan-27-Upaya

Surbakti, H. (2010). Pemodelan sebaran sedimen tersuspensi dan pola arus Di Perairan Pesisir Banyuasin, Sumatera Selatan. Thesis. Postgraduate, Bogor Agricultural University: Bogor.

Yenrina, R. (2015). Metode Analisis Bahan Pangan dan Komponen Bioaktif. Andalas University Press: Padang.

\section{Copyrights}

Copyright for this article is retained by the author(s), with first publication rights granted to the journal.

This is an open-access article distributed under the terms and conditions of the Creative Commons Attribution license (http://creativecommons.org/licenses/by/4.0/). 